\title{
Pengaruh Kombinasi Tapioka dan Tepung Kedelai terhadap Kualitas Sosis Ikan Kakap Putih (Lates calcarifer Bloch)
}

\author{
The Influence of Cassava Starch and Soybean Flour Combinations to the Quality of \\ Seabass (Lates calcarifer Bloch) Sausage Production
}

\author{
Prima Novi Agatha, Ekawati Purwijantiningsih*, F. Sinung Pranata \\ Fakultas Teknobiologi, Universitas Atma Jaya Yogyakarta, Jl. Babarsari 44 Yogyakarta 55281 \\ E-mail: purwija@mail.uajy.ac.id *Penulis untuk korespondensi
}

\begin{abstract}
Sausage is food product made from mix ture of minced meat (contain meat more than $75 \%)$, flour or starch with or without additional spices, and other allowed food additive. Sausage made from meat usually has a higher content of fat, which in many cases usually caused serious health problem. To reduce the fat content in sausages, the researchers try to combine cassava starch with soybean flour. Soybean flour was used in combination with cassava starch because it reduced of cholesterol in blood, reduced oil absorption while frying. Soybean flour is a kind of food material that has higher content of protein but low fat, and it has complete essential amino acids. This research was conducted to find out the influence of cassava starch and soybean flour combinations to produce good quality of seabass sausages. In this experiment, cassava starch and soybean flour combination were as follows 90:10; 80:20; and 70:30. The result showed that the combination of cassava starch with soybean flour increase water content, ash content, protein content and fat content but elasticity and carbohydrate content were decrease.
\end{abstract}

Key words: sausage, soybean flour, cassava starch, seabass

Diterima: 24 November 2007, disetujui: 21 Januari 2008

\section{Pendahuluan}

Sosis merupakan bahan pangan sistem emulsi yang terutama dibuat dari daging. Daging selain sebagai sumber protein juga mengandung lemak dan kolesterol yang tinggi. Adanya lemak dan kolesterol tersebut mengakibatkan sosis kurang banyak diminati konsumen terutama yang memiliki masalah dengan kolesterol darah tinggi. Untuk mengurangi kadar kolesterol dalam sosis daging perlu dicari alternatif lain bahan dasar sosis selain daging serta penambahan bahan nabati untuk pembuatan sosis yang tentunya tidak banyak mengakibatkan perubahan pada sifat sosis.

Ikan merupakan bahan pangan yang sangat dibutuhkan oleh manusia karena mengandung asam amino esensial yang lengkap dan kecukupannya menyediakan asam amino lisin, metionin, dan histidin yang merupakan asam amino pembatas pada kebanyakan bahan pangan nabati, di samping itu kandungan lemak dan kolesterolnya rendah, merupakan sumber asam lemak tidak jenuh omega 3 serta mengandung mineral yang tinggi (Suhartini dan Nur, 2005).

Ikan kakap putih (Lates calcarifer Bloch) pada umumnya dikonsumsi dalam keadaan segar. Namun ikan segar mudah sekali busuk. Beberapa upaya dilakukan untuk meningkatkan ragam konsumsi ikan dalam rangka pemenuhan kebutuhan protein hewani, yaitu diversifikasi dalam pengolahan ikan diantaranya pembuatan bakso ikan, nugget ikan atau sosis ikan. Selama ini, sosis ikan belum banyak dikenal oleh masyarakat. Ikan kakap 
putih merupakan salah satu ikan yang sangat digemari oleh masyarakat Indonesia karena daging ikan kakap putih lebih tebal, gurih, dan tidak amis (Genisa dan Mayunar, 2003).

Salah satu bahan yang diperlukan dalam pembuatan sosis adalah ekstender. Menurut Price dan Scheweighert (1971), komponen sosis diantaranya adalah ekstender, yaitu bahan yang ditambahkan dalam formulasi daging untuk mengurangi biaya formulasi, meningkatkan flavor, sifat irisan, cooking yield, dan stabilitas emulsi. Ekstender terdiri dari bahan perekat (binder) dan bahan pengisi (filler). Binder mengandung protein yang tinggi dibanding filler sedangkan filler memiliki komposisi utama karbohidrat.

Umumnya pembuatan sosis menggunakan isolat protein kedelai, namun harganya cukup mahal. Penelitian kali ini menggunakan tepung kedelai karena mudah dibuat serta memiliki nilai protein yang tinggi. Tepung kedelai memiliki banyak kegunaan karena relatif mudah dicampur dengan tepung lain (serealia, umbi-umbian) dan dapat diolah menjadi berbagai produk pangan, seperti roti, makanan bayi dan lain-lain. Selain itu tepung kedelai juga dapat mencegah penyerapan lemak dalam proses penggorengan (Heinnermen, 2003).

Tepung tapioka merupakan bahan pengisi yang umumnya digunakan dalam pembuatan sosis. Tepung tapioka mempunyai banyak kegunaan, antara lain sebagai bahan pengental, bahan pengisi dan bahan pengikat dalam industri makanan. Tepung tapioka digunakan dalam pembuatan sosis dan bakso berfungsi sebagai pengenyal (Margono et al., 1993). Pada penelitian kali ini pembuatan sosis ikan akan dikombinasikan tepung tapioka dan tepung kedelai. Penambahan tepung kedelai diharapkan dapat menjadi pengemulsi alami dan meningkatkan gizi sosis ikan kakap putih sehingga dihasilkan sosis yang lebih sehat.

Tujuan penelitian ini adalah untuk mengetahui perbedaan pengaruh kombinasi tepung tapioka dan tepung kedelai terhadap sifat kimia, fisik dan mikrobiologis sosis ikan kakap putih.

\section{Metode Penelitian}

\section{Bahan}

Bahan-bahan yang digunakan adalah ikan kakap putih yang diperoleh dari Pasar Swalayan Carefour, tepung tapioka, tepung kedelai, air, merica halus, jahe bubuk, pala bubuk, bawang putih, shortening, garam halus, gula, susu skim, natrium tripolifosfat, gula, telur, es batu, medium Plate Count Agar (PCA), medium Brilliant Green Lactose Bile Broth (BGLB), indikator PP, batu didih, aquadest steril, HCL 0,1 N, MR, petroleum eter (PE), kapas, alumunium foil, alkohol 70\%, katalisator $\left(\mathrm{K}_{2} \mathrm{SO}_{4}+\mathrm{CuSO}_{4}\right), \mathrm{H}_{2} \mathrm{SO}_{4}$ pekat, dan $\mathrm{NaOH} 0,1 \mathrm{~N}$.

\section{Rancangan percobaan dan analisis data}

Rancangan percobaan yang digunakan adalah rancangan acak lengkap (RAL) dengan 3 kombinasi perlakuan dan 1 kontrol serta dilakukan 3 kali ulangan. Perlakuan 1 adalah kombinasi tepung tapioka dan tepung kedelai 90:10 (b/b). Perlakuan 2 adalah kombinasi tepung tapioka dan tepung kedelai 80:20 (b/b). Perlakuan 3 adalah kombinasi tepung tapioka dan tepung kedelai 70:30 (b/b). Sedangkan kontrol menggunakan tepung tapioka tanpa dikombinasikan dengan tepung kedelai. Data yang diperoleh dianalisis dengan ANAVA. Selanjutnya untuk mengetahui letak beda nyata dilakukan DMRT (Duncan's Multiple Range Test).

\section{Cara Kerja}

\section{Pembuatan tepung kedelai}

Kedelai utuh disortasi, direndam selama 4-6 jam, selanjutnya direbus selama 30 menit pada suhu $80^{\circ} \mathrm{C}$. Setelah itu dilakukan pengupasan kulit kemudian dikeringkan pada pengeringan selama 6 jam pada suhu $50-60^{\circ} \mathrm{C}$. Kedelai yang telah kering digiling dan diayak 60 mesh (Widowati et al., 1998).

\section{Pembuatan sosis ikan kakap putih}

Daging ikan kakap putih sebanyak 250 gram digiling sampai lumat dan dicampur garam setengah sendok makan dan bumbubumbu yang telah dihaluskan (bawang putih 
satu siung, merica bubuk dua gram, pala bubuk satu setengah gram, jahe bubuk setengah gram), gula pasir satu sendok makan, susu skim 20 gram, shortening 15 gram, es batu empat kubus, putih telur, dan tepung tapioka 25 gram), lalu digiling sampai homogen. Adonan daging bercampur bumbu dimasukkan ke dalam stuffer dan adonan yang keluar dari stuffer langsung dimasukkan ke dalam selongsong yang disebut casing. Adonan dalam bentuk bulat panjang kemudian diikat sesuai dengan panjang yang diinginkan. Perebusan dilakukan secara bertahap yaitu perebusan dengan air panas suhu $60^{\circ} \mathrm{C}$ selama $15-20$ menit, kemudian dilanjutkan perebusan pada suhu $80-90^{\circ} \mathrm{C}$ selama 15 menit. Perebusan sosis ini dilakukan secara bertahap untuk mencegah terjadinya pemecahan pada sosis apabila perebusan dilakukan langsung pada suhu tinggi. Sosis yang sudah matang kemudian digunting dari benangnya (Anonim, 2004).

Analisis parameter kualitas sosis ikan kakap putih meliputi analisis kadar air, kadar abu, kadar protein, kadar lemak, dan kadar karbohidrat mengacu pada Sudarmadji et al., (1997), analisis tekstur mengacu Winarni (1995), perhitungan angka lempeng total mengacu Anonim (1984), dan uji Coliform mengacu pada Fardiaz (1989).

\section{Hasil dan Pembahasan}

\section{Kadar air}

Air merupakan komponen penting dalam bahan makanan. Menurut Naruki (1991), kadar air sosis matang tidak boleh melebihi empat kali kadar protein (hasil analisis) ditambah $10 \%$.

Kadar air sosis ikan kakap putih berkisar antara 15,96\% sampai dengan 16,99\%. Hasil analisis kombinasi tepung tapioka dengan tepung kedelai menunjukkan bahwa penambahan tepung kedelai tiap perlakuan berpengaruh terhadap kadar air sosis ikan kakap putih (Tabel 1). Kadar air tertinggi terdapat pada sosis ikan kakap putih pada perlakuan 70:30 dengan penggunaan tepung kedelai paling banyak. Menurut Praptiningsih et al., (2002), kandungan protein yang tinggi pada suatu bahan, pada umumnya tingkat penyerapan airnya juga tinggi.

Tabel 1. Kadar air (\% b/b) sosis ikan kakap putih dengan kombinasi tepung tapioka dan tepung kedelai

\begin{tabular}{cc}
\hline \hline Kombinasi & Kadar Air (\% b/b) \\
(Tepung Tapioka : Tepung Kedelai) & $15,96^{\mathrm{a}}$ \\
\hline \hline $100: 0$ (Kontrol) & $16,07^{\mathrm{a}}$ \\
$90: 10$ & $16,31^{\mathrm{a}}$ \\
$80: 20$ & $16,99^{\mathrm{b}}$ \\
\hline $70: 30$ & \\
\hline \hline
\end{tabular}

Keterangan: Angka yang diikuti huruf yang sama tidak beda nyata pada taraf kepercayaan 95\%

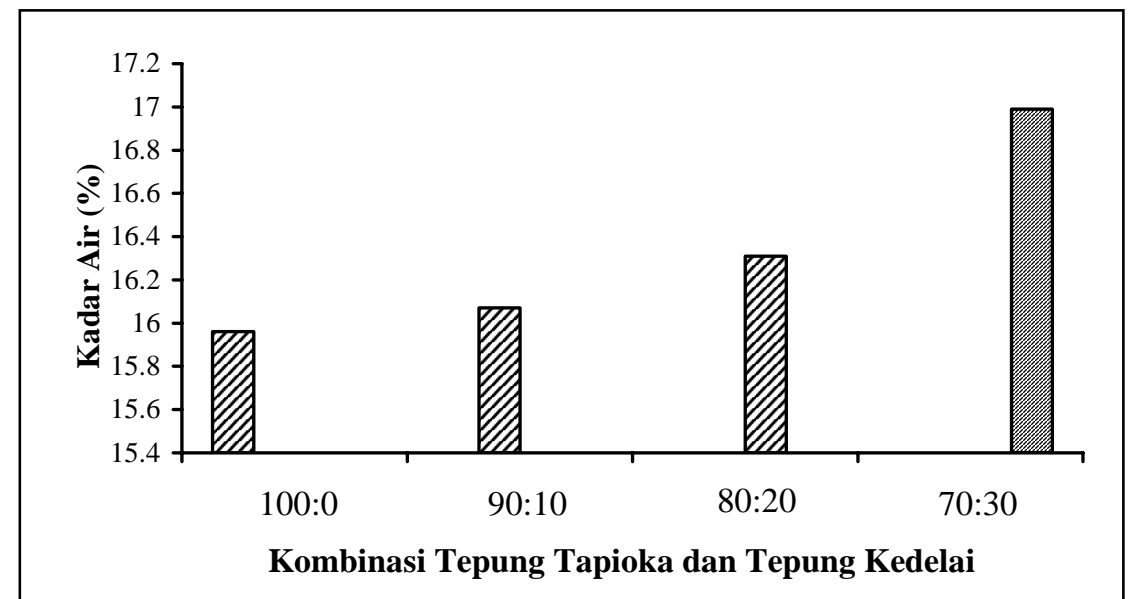

Gambar 1. Kadar air (\% b/b) sosis ikan kakap putih dengan kombinasi tepung tapioka dan tepung kedelai 


\section{Kadar abu}

Sosis ikan kakap memiliki kadar abu yang cukup tinggi yaitu berkisar antara 3,16\% sampai dengan 4,83\% (Tabel 2 dan Gambar 2). Kadar abu terendah dijumpai pada perlakuan kontrol. Kadar abu sosis ikan kakap putih ditentukan oleh bahan-bahan yang digunakan. Ikan kakap putih yang berasal dari laut memiliki kandungan mineral yang cukup tinggi begitu pula dengan tepung kedelai. Hasil uji kadar abu sosis ikan kakap putih menunjukkan hasil yang berbeda nyata, semakin banyak tepung kedelai yang digunakan maka kadar abunya semakin meningkat. Hal ini disebabkan tingginya kandungan mineral tepung kedelai

Menurut Kanoni et al., 1991, ikan laut kaya akan mineral iodin. Menurut Tranggono (1991), ikan memiliki kandungan mineral garam fosfat dan kalsium pada daging skeletonnya. Menurut Manullang dan Elingsari (1995), jumlah garam dan mineral yang terdapat pada produk, mencerminkan kadar abu produk.

\section{Kadar protein}

Kadar protein yang diperoleh berkisar antara 19,72\% sampai 38,11\% (Tabel 3). Hasil terendah diperoleh dari perlakuan kontrol, yaitu tanpa penggunaan tepung kedelai. Meningkatnya jumlah kadar protein masingmasing perlakuan seiring meningkatnya tepung kedelai yang digunakan (Gambar 3). Hal ini disebabkan karena diantara jenis kacangkacangan, kedelai merupakan sumber protein yang terbaik (Koswara, 1995). Selain itu tingginya kadar protein sosis ikan kakap dikarenakan penggunaan ikan kakap yang memiliki kandungan protein yang tinggi yaitu berkisar $20 \mathrm{~g}$ dalam $100 \mathrm{~g}$ bahan, penggunaan susu skim serta putih telur.

Menurut Kanoni et al., (1992), kandungan protein ikan sangat tinggi dibandingkan dengan protein hewan lainnya, dengan asam amino esensial sempurna, karena hampir semua asam amino esensial terdapat pada daging ikan. Menurut Kanoni et al., (1992), protein daging ikan sangat cocok untuk membuat emulsi minyak dalam air karena mempunyai nilai HLB (Hidrophilic Lipophylic Balance) yang sangat tinggi, yaitu 10,3-41,4 ml minyak/100 gram protein. Protein tersebut berfungsi sebagai penstabil dan pengemulsi yang mempengaruhi sifat fisik sosis terutama kenampakan irisan. Hasil kadar protein sosis ikan kakap putih yang dihasilkan sesuai dengan SNI mutu sosis daging yaitu minimal jumlah protein sosis adalah $13 \%$.

\section{Kadar lemak}

Menurut Tranggono (1991), kandungan lemak pada ikan ada kaitannya dengan cita rasa dan kelezatan. Pada umumnya jika kandungan lemaknya tinggi, maka cita rasanya lebih enak. Menurut Price dan Scheweighert (1971), lemak berfungsi memberikan sifat juiceness, tekstur dan cita rasa sosis.

Lemak sosis ikan kakap putih berkisar 11,27\% sampai 24,10\% (Tabel 4). Menurut Arief et al., (1999), kadar lemak sosis masak tidak boleh melebihi 30\%, maka kadar lemak sosis ikan kakap putih masih memenuhi standar tersebut dan memenuhi standar SNI sosis daging (Anonim, 1995) yaitu maksimal 25\%.

Tabel 2. Kadar abu (\% b/b) sosis ikan kakap putih dengan kombinasi tepung tapioka dan tepung kedelai

\begin{tabular}{cc}
\hline \hline Kombinasi & Kadar Abu (\% b/b) \\
(Tepung Tapioka : Tepung Kedelai) & $3,16^{\mathrm{a}}$ \\
\hline \hline 100:0 (Kontrol) & $4,33^{\mathrm{b}}$ \\
$90: 10$ & $4,53^{\mathrm{bc}}$ \\
$70: 20$ & $4,83^{\mathrm{c}}$ \\
\hline \hline
\end{tabular}

Keterangan: Angka yang diikuti huruf yang sama tidak beda nyata pada taraf kepercayaan 95\% 
Tabel 3. Kadar protein (\% b/b) sosis ikan kakap putih dengan kombinasi tepung tapioka dan tepung kedelai

\begin{tabular}{cc}
\hline \hline Kombinasi & Kadar Protein (\% b/b) \\
(Tepung Tapioka : Tepung Kedelai) & $19,72^{\mathrm{a}}$ \\
\hline \hline $100: 0$ (Kontrol) & $35,46^{\mathrm{b}}$ \\
$90: 10$ & $36,41^{\mathrm{b}}$ \\
$80: 20$ & $38,11^{\mathrm{c}}$ \\
$70: 30$ & \\
\hline \hline
\end{tabular}

Keterangan: Angka yang diikuti huruf yang sama tidak beda nyata pada taraf kepercayaan 95\%

Tabel 4. Kadar lemak (\% b/b) sosis ikan kakap putih dengan kombinasi tepung tapioka dan tepung kedelai

\begin{tabular}{cc}
\hline \hline Kombinasi & Kadar Lemak (\% b/b) \\
(Tepung Tapioka : Tepung Kedelai) & $11,27^{\mathrm{a}}$ \\
\hline \hline $100: 0$ (Kontrol) & $19,23^{\mathrm{b}}$ \\
$90: 10$ & $21,49^{\mathrm{b}}$ \\
$80: 20$ & $24,10^{\mathrm{c}}$ \\
$70: 30$ & $2 \%$ \\
\hline \hline
\end{tabular}

Keterangan: Angka yang diikuti huruf yang sama tidak beda nyata pada taraf kepercayaan 95\%

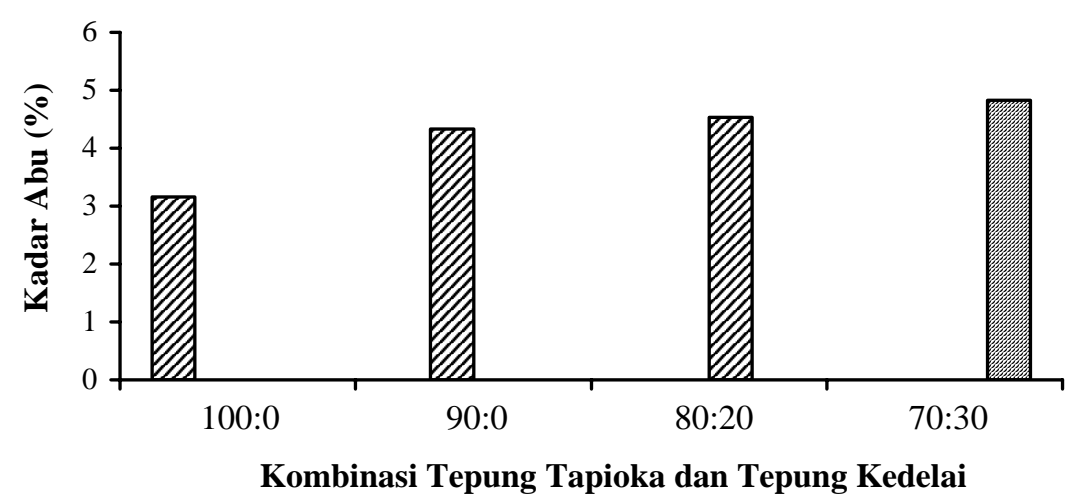

Gambar 2. Kadar abu (\% b/b) sosis ikan kakap putih dengan kombinasi tepung tapioka dan tepung kedelai

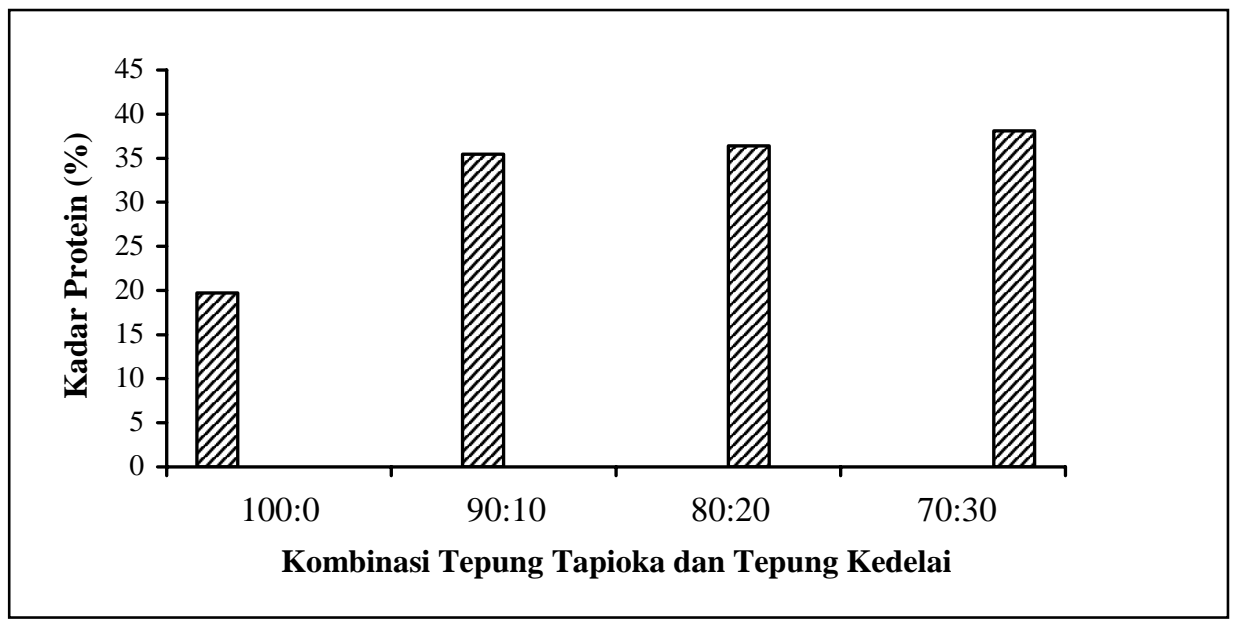

Gambar 3. Kadar protein (\%b/b) sosis ikan kakap putih dengan kombinasi tepung tapioka dan tepung kedelai 
Hasil analisis kadar lemak menunjukan hasil yang berbeda nyata. Kadar lemak sosis ikan kakap putih meningkat seiring meningkatnya jumlah tepung kedelai yang digunakan ke dalam adonan sosis karena kadar lemak tepung kedelai tinggi yaitu 17,96\% dibandingkan kadar lemak tepung tapioka dan lemak ikan kakap putih sehingga dengan semakin banyaknya tepung kedelai yang digunakan maka kadar lemaknya semakin tinggi (Gambar 4).

\section{Kadar karbohidrat}

Kadar karbohidrat sosis ikan kakap putih hasil penelitian berkisar antara 15,97\% sampai 49,88\% (Tabel 5). Hasil analisis tersebut menunjukkan hasil yang berbeda nyata pada tiap perlakuan, antara kontrol dengan perlakuan dengan kombinasi tepung kedelai. Hasil kadar karbohidrat tertinggi diperoleh dari kontrol, yaitu sosis tanpa adanya penambahan tepung kedelai yaitu sebesar 49,88\% dan hasil paling rendah pada kombinasi tepung kedelai paling tinggi yaitu perlakuan 70:30.

Semakin tinggi konsentrasi kombinasi penambahan tepung kedelai maka kadar karbohidratnya semakin kecil. Hal tersebut dikarenakan pada penelitian ini semakin besar perbandingan tepung tapioka dengan tepung kedelai maka jumlah penambahan tepung tapioka semakin kecil sedangkan jumlah penambahan tepung kedelai semakin besar sehingga kadar karbohidratnya semakin menurun (Gambar 5).

\section{Analisis elastisitas}

Elastisitas makanan didefinisikan sebagai kemampuan makanan untuk kembali ke bentuk semula setelah diberi tekanan (Manullang dan Elingsari, 1995). Menurut deMan (1997) elastisistas suatu bahan terjadi karena adanya gaya kohesi antara partikelpartikel penyusun bahan pangan tersebut.

Elastisitas sosis ikan kakap putih yang dihasilkan cukup baik, hal ini berkaitan dengan bahan dasar yang digunakan yaitu ikan kakap putih. Ikan kakap putih yang segar memiliki protein miofibril dalam jumlah yang cukup sehingga jika bereaksi dengan air dan garam akan terbentuk "brine" yang akan menentukan stabilitas emulsi (Naruki, 1991). Elastisitas sosis ikan kakap putih dipengaruhi pula oleh banyaknya tepung kedelai yang dikombinasikan dengan tepung tapioka ke dalam adonan. Semakin banyak tepung kedelai yang digunakan maka elastisitas sosis ikan kakap putih semakin rendah atau menjadi lembek (Tabel 6 dan Gambar 6).

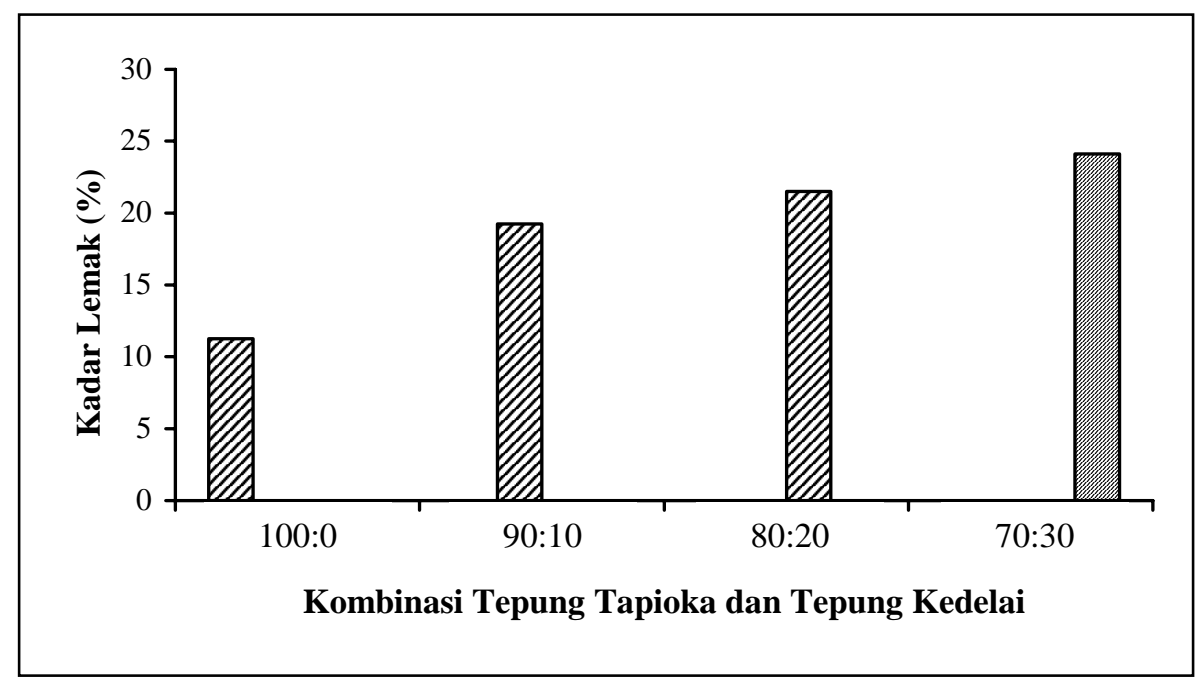

Gambar 4. Kadar lemak (\% b/b) sosis ikan kakap putih dengan kombinasi tepung tapioka dan tepung kedelai 
Tabel 5. Kadar karbohidrat (\% b/b) sosis ikan kakap putih dengan kombinasi tepung tapioka dan tepung kedelai

\begin{tabular}{cc}
\hline \hline Kombinasi & Kadar Karbohidrat (\% b/b) \\
(Tepung Tapioka : Tepung Kedelai) & $49,88^{\mathrm{d}}$ \\
\hline \hline 100:0 (Kontrol) & $24,91^{\mathrm{c}}$ \\
$90: 10$ & $21,26^{\mathrm{b}}$ \\
$80: 20$ & $15,97^{\mathrm{a}}$ \\
$70: 30$ & \\
\hline \hline
\end{tabular}

Keterangan: Angka yang diikuti huruf yang sama tidak beda nyata pada taraf kepercayaan 95\%

Tabel 6. Hasil analisis elastisitas $\left(\mathrm{N} / \mathrm{mm}^{2}\right)$ sosis ikan kakap putih dengan kombinasi tepung tapioka dan tepung kedelai

Elastisitas Sosis Ikan Kakap Putih (N/mm²) Pada Kombinasi Tepung Tapioka dan Tepung Kedelai

\begin{tabular}{cccc}
\hline \hline Kontrol $(100: 0)$ & $90: 10$ & $80: 20$ & $70: 30$ \\
\hline $16597,00^{c}$ & $15758,00^{\mathbf{a b}}$ & $15519,00^{\mathbf{a b}}$ & $13887,00^{\text {abc }}$ \\
\hline \hline
\end{tabular}

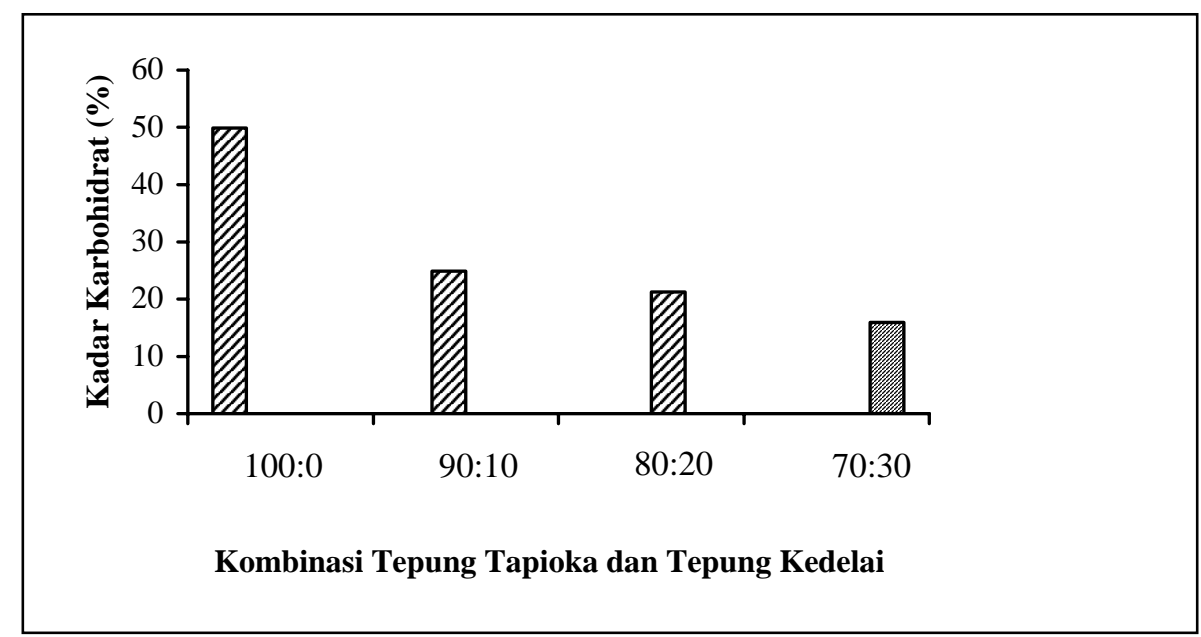

Gambar 5. Kadar karbohidrat (\% b/b) sosis ikan kakap putih dengan kombinasi tepung tapioka dan tepung kedelai

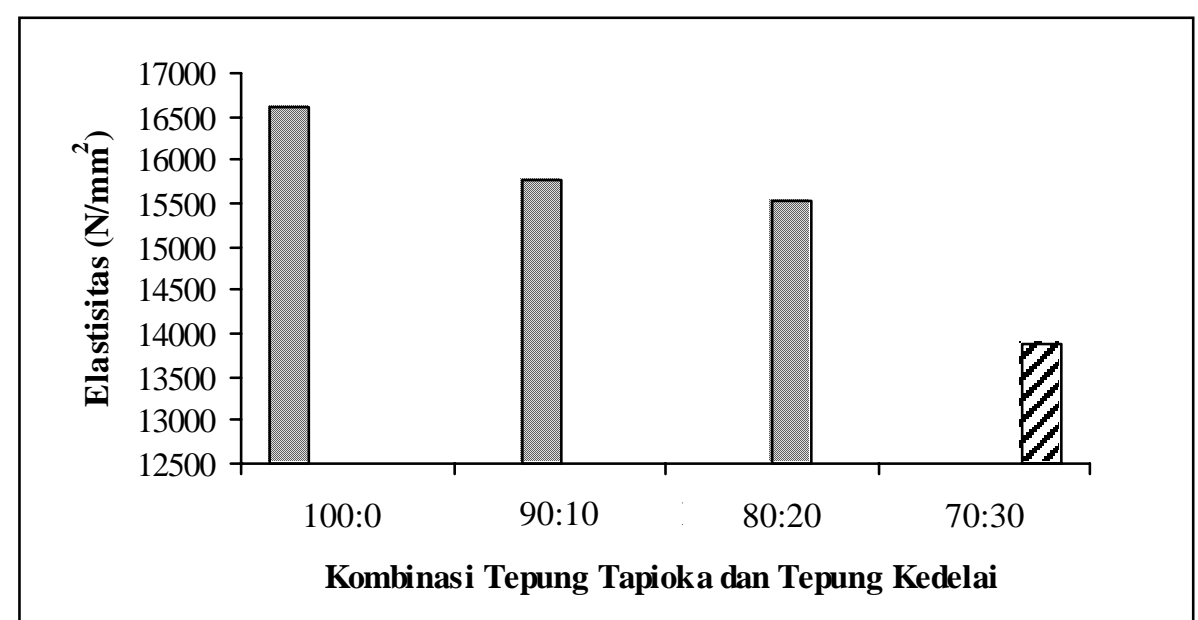

Gambar 6. Elastisitas $\left(\mathrm{N} / \mathrm{mm}^{2}\right)$ sois ikan kakap putih dengan kombinasi tepung tapioka dan tepung kedelai 
Berdasarkan hasil analisis elastisitas, nilai elastisitas sosis ikan kakap putih berkisar antara 16579 sampai $13887 \mathrm{~N} / \mathrm{mm}$. Menurut Arief et al., (1999), kekerasan sosis dipengaruhi oleh bahan pengisi yang ditambahkan ke dalam adonan ikan lumat. Ketika zat pati ditambahkan ke dalam adonan daging lumat, maka adonan akan mengeras dan mudah dipatahkan. Pemanasan saat proses perebusan sosis juga berpengaruh terhadap tekstur sosis ikan kakap putih. Lama dan suhu pemasakan juga berpengaruh terhadap kualitas tekstur sosis.

\section{Perhitungan jumlah total mikrobia uji coliform sosis ikan kakap putih}

\section{Angka lempeng total}

Total mikrobia sosis ikan kakap putih berkisar antara $1,30 \times 10^{2} \mathrm{CFU} / \mathrm{g}$ sampai 4,07 x $10^{2} \mathrm{CFU} / \mathrm{g}$ (Tabel 7 dan Gambar 7). Hal ini disebabkan bahan baku sosis ikan yang memang sejak awal sudah mengandung bakteri sehingga saat dipanaskan tidak semua bakteri mati, khususnya bakteri tahan panas. Ikan yang sudah mati akan kehilangan proses-proses dalam tubuhnya sehingga enzim-enzimnya tidak aktif lagi sehingga setelah ikan mati mudah sekali ditumbuhi bakteri. Namun hasil uji tersebut masih sesuai dengan SNI Tahun 1995 yaitu maksimal jumlah total bakteri pada sosis adalah $10^{5} \mathrm{CFU} / \mathrm{g}$.

Rendahnya nilai angka lempeng total dari sosis ikan kakap putih disebabkan karena setelah pengolahan sosis disimpan pada lemari pendingin yang bersuhu $10^{\circ} \mathrm{C}$, sehingga kondisi lingkungan dapat menghambat pertumbuhan mikrobia. Menurut Trihendrokesuwo et al., (1989), mikrobia yang dapat tumbuh di dalam makanan yang disimpan dalam lemari pendingin disebut bakteri psikrofilik. Meskipun demikian pertumbuhan bakteri di dalam sosis ikan kakap putih tidak dapat dihindari walaupun telah melalui proses pemanasan saat pemasakan tidak semua jenis bakteri mati karena ada beberapa jenis bakteri tertentu yang tahan panas. Menurut Trihendrokesuwo et al., (1989), beberapa jenis bakteri tahan panas tersebut adalah Bacillus dan Clostridium. Bacillus dan Clostridium dapat membentuk spora sehingga masih bisa bertahan hidup.

\section{Coliform}

Hasil uji Coliform menunjukkan bahwa sosis ikan kakap putih kontrol dan sosis ikan kakap putih dengan kombinasi tepung tapioka dan tepung kedelai masih memenuhi syarat mutu SNI yaitu $<3$ untuk perlakuan kontrol, 90:10, 80:20, dan 70:30 (Tabel 8). Maksimal jumlah bakteri bentuk koli menurut SNI adalah 10 APM/g. Nilai MPN yang diperoleh rendah karena saat pengolahan sosis ikan kakap putih, sosis direbus melalui dua tahap yaitu pada suhu $60^{\circ} \mathrm{C}$ selama 30-45 menit dan pada suhu 80$90^{\circ} \mathrm{C}$ selama 15-20 menit sehingga bakteri jenis koli dapat diminimalkan.

Tabel 7. Jumlah total mikrobia pada kombinasi tepung tapioka dan tepung kedelai

\begin{tabular}{cccc}
\hline \hline \multicolumn{4}{c}{ Jumlah total mikroorganisme (CFU/g) pada kombinasi tepung tapioka dan tepung kedelai } \\
\hline Kontrol $(100: 0)$ & $90: 10$ & $80: 20$ & $70: 30$ \\
\hline $1,30 \times 10^{2 \mathrm{a}}$ & $1,80 \times 10^{2 \mathrm{a}}$ & $2,44 \times 10^{2 \mathrm{a}}$ & $4,07 \times 10^{2 \mathrm{ab}}$ \\
\hline \hline
\end{tabular}

Tabel 8. Hasil uji coliform (APM/g) sosis ikan kakap putih dengan kombinasi tepung tapioka dan tepung kedelai

\begin{tabular}{cc}
\hline \hline Sampel & Nilai MPN (APM/g) \\
\hline \hline Kontrol (100:0) & $<3$ \\
$90: 10$ & $<3$ \\
$80: 20$ & $<3$ \\
$70: 30$ & $<3$ \\
\hline \hline
\end{tabular}




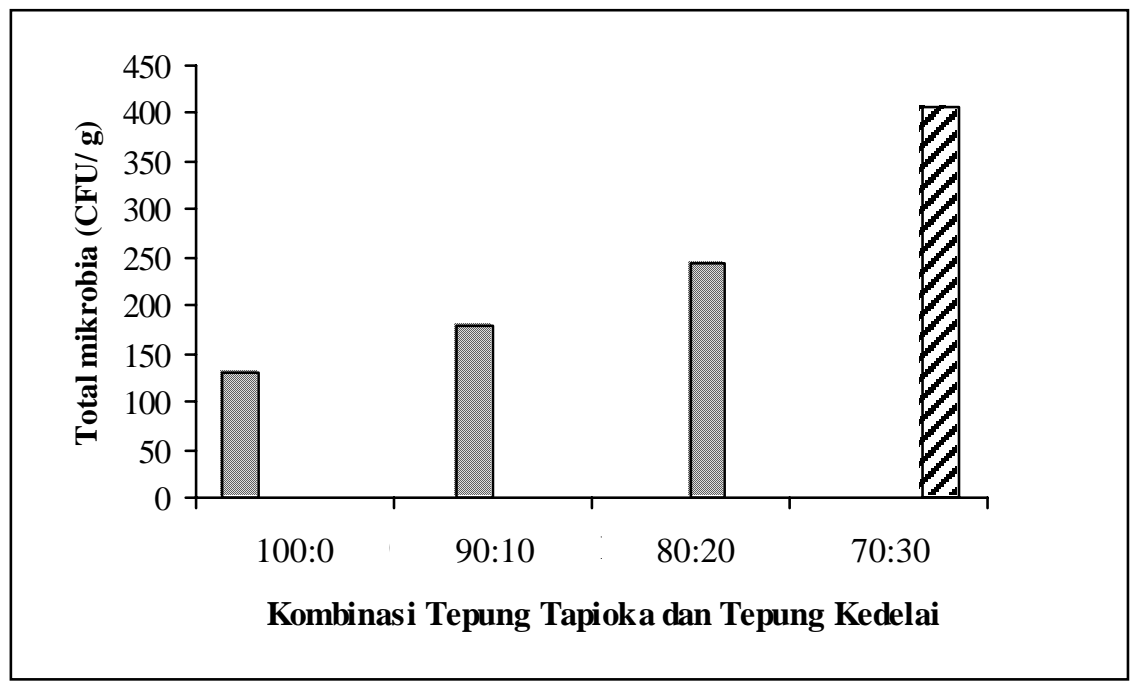

Gambar 7. Jumlah total mikrobia pada kombinasi tepung tapioka dan tepung kedelai

\section{Kesimpulan}

Kombinasi tepung tapioka dan tepung kedelai berpengaruh positif terhadap kualitas sosis ikan kakap putih. Semakin banyak kombinasi tepung kedelai dan semakin sedikit tepung tapioka pada sosis ikan kakap putih menyebabkan kadar protein, kadar lemak, kadar air, kadar abu, angka lempeng total dan total mikrobia namun daya elastisitas dan kadar karbohidratnya semakin kecil.

\section{Daftar Pustaka}

Anonim. 1984. Bacteriological Analytical Manual, Division of Microbiology Center for Food Safety and Applied Nutrition U.S. Food and Drugs Administration.

Anonim. 1995. Mutu dan Cara Uji Sosis Daging, SNI 013820-1995. Pusat Standarisasi Departemen Perindustrian, Jakarta.

Anonim. 2004. Pengolahan Bakso dan Sosis Ikan Patin, Pusat Riset Pengolahan Produk dan Sosial Ekonomi Kelautan dan Perikanan, Jakarta.

Arief, D.Z., Hilma, Y. dan Yudi, G. 1999. Perbandingan Ikan Tongkol dengan Ampas Tahu dan Perbandingan Tepung Tapioka dengan Tepung Kacang Merah dalam Meningkatkan Mutu Sosis Ikan Tongkol (Katsuwonus pelamis), Sem. Nas. Teknologi Pangan PATPI, Jakarta.

deMan, J.M. 1997. Kimia Makanan, Institut Teknologi Bandung, Bandung.
Fardiaz, S. 1989. Petunjuk Laboratorium Analisis Mikrobiologi Pangan, PAU Pangan dan Gizi, Universitas Gadjah Mada, Yogyakarta.

Genisa, A.S. dan Mayunar. 2003. Budidaya Ikan Kakap Putih, Penerbit PT. Gramedia Widiasarana Indonesia, Jakarta.

Heinnermen, J. 2003. Khasiat Kedelai Bagi Kesehatan Anda, Penerbit Prestasi Pustaka, Jakarta.

Kanoni, S., Suhardi dan Agnes, M. 1991. Pemanfaatan Ampas Tahu Sebagai Perekat Sosis Bologna yang Dimodifikasi, Laporan Penelitian Fakultas Teknologi Pertanian, Universitas Gadjah Mada, Yogyakarta.

Kanoni, S., Suwedo, H. dan Sri, N. 1992. Biokimia dan Teknologi Protein Hewani, PAU Pangan dan Gizi, Universitas Gadjah Mada, Yogyakarta.

Koswara, S. 1995. Kacang-Kacangan Sumber Serat yang Kaya Gizi. http://www.ebookpangan.com/ Artikel/Kacangkacangan,\%20Sumber\%20Ser at\%20yang\%20Kaya\%20Gizi.pdf.12/04/2006

Manullang, M. dan Elingsari, T. 1995. Pengaruh Bahan Pengikat dan Emulsifier Terhadap Mutu Nugget Ikan (Scomberomorus commersoni) Selama Penyimpanan pada Suhu Beku. Bull. Teknologi dan Industri Pangan VI (1): 42-47.

Margono, T., Detty, S. dan Sri. 1993. Buku Panduan Teknologi Pangan, Pusat Informasi Wanita dalam Pembangunan PDII-LIPI bekerjasama dengan Swiss Development Cooperation.

Naruki, S. 1991. Kimia dan Teknologi Pengolahan Daging, PAU Pangan dan Gizi, Universitas Gadjah Mada, Yogyakarta. 
Praptiningsih, Y.S., Tamtarini dan Andreas, S. 2002. Sifat-Sifat Sosis Ikan Lemuru dengan Variasi Macam dan Jumlah Bahan Pengisi, Sem. Nas. PATPI, Malang.

Price, J.F. dan Scheweighert, B.S. 1971. The Science of Meat and Meat Product, Freeman, W.H. and Company, San Fransisco.

Sudarmadji, S., Haryono, B. dan Suhardi. 1997. Prosedur Analisa Bahan Makanan dan Pertanian, Penerbit Liberty, Yogyakarta.

Suhartini, S. dan Nur, H. 2005, Olahan Ikan Segar, Penerbit Trubus Agrisarana, Surabaya.

Tranggono. 1991. Analisa Hasil Perikanan, PAU Pangan dan Gizi, Universitas Gadjah Mada, Yogyakarta.

Trihendrokesuwo, Wibowo, D., Koesnijo, R., Romas, M.A., Haksohusodo, S., Saleh, S., Ristanto, Mustafa, M., Rintiswati, N., Apandi, T. dan Praseno. 1989. Petunjuk Laboratorium Mikrobiologi Pangan, PAU Pangan dan Gizi, Universitas Gadjah Mada, Yogyakarta.

Widowati, S., Rochmadi, A.F., Kustiyah, L., Slamet, D.S. dan Darmadjati, D.S. 1998. Pengolahan Bahan Makanan Campuran (BMC) Sebagai Pengisi Makanan Jajanan Untuk Anak Sekolah Dasar, Sem. Nas. Makanan Tradisional, Institut Pertanian Bogor, Bogor.

Winarni, D. 1995. Kajian Potensi Beberapa Bahan Tambahan Kue Kering. Skripsi. Fakultas Teknologi Pertanian, Universitas Gadjah Mada, Yogyakarta. 